\section{'ValleGrande': An Early Maturing, Low-chilling Peach for Subtropical Climates}

\author{
Robert E. Rouse ${ }^{1}$ \\ Texas A\&M University Research and Extension Center at Weslaco, 2415 \\ East Highway 83, Weslaco, TX 78596
}

\section{David H. Byrne ${ }^{2}$ \\ Department of Horticulture, Texas A\&M University, College Station, TX 77843}

Additional index words. Prunus persica, fruit breeding, low-chilling
'ValleGrande' is a low-chilling (200 chilling units), high-yielding, good-quality, early maturing (mid-April), semi-freestone peach cultivar. It is adapted to subtropical climatic areas and is suitable for commercial, U-pick, and home plantings in the Lower Rio Grande Valley and other parts of southern Texas.

In most years, 'ValleGrande' matures the 3rd week of April in the Lower Rio Grande Valley. This is 1 week after 'EarliGrande', the earliest-maturing peach cultivar. Maturity of 'ValleGrande' follows 'EarliGrande' (Bowen, 1980) and 'Flordaprince' (Sherman et al., 1982) and precedes 'TropicBeauty' (Rouse and Sherman, 1989) in late April and 'TropicSweet' (Rouse and Sherman, 1987) and 'FlordaGrande' (Rouse et al., 1985) in May. 'ValleGrande' complements other peach cultivars adapted to subtropical climates similar to south Texas by filling an opening in the marketing season not filled by the other cultivars.

\section{Origin} cultivar 'EarliGrande' that was released in 1980 by The Texas Agricultural Experiment Station, Texas A\&M Univ. In 1983 'ValleGrande' was given the number RGV83-1 after it was observed as a budded tree of 'EarliGrande' that had later-maturing and larger fruit with more external red blush than 'EarliGrande'. The parentage of 'Vallegenes come from 'Jewel' and 'Early Amber'.

\section{Description and performance}

Flowers of 'ValleGrande' are self-fertile, large, pink, and nonshowy. Pollen is bright yellow and abundant. Bloom normally occurs in late January to early February in the Lower Rio Grande Valley. Flower bud set is

Received for publication 25 Sept. 1989. The cost of publishing this paper was defrayed in part by the payment of page charges. Under postal regulations, this paper therefore must be hereby marked advertisement solely to indicate this fact.

'Research Horticulturist.

${ }^{2}$ Research Geneticist.
'ValleGrande' is a bud mutation from the Grande' is shown in Fig. 1. The low-chilling moderate, and early thinning to 15 or $20 \mathrm{~cm}$ apart is necessary to obtain fruit 6 to $7 \mathrm{~cm}$ in diameter.

Largest fruit (Fig. 2) range from 6.4 to $7.0 \mathrm{~cm}$ in diameter and weigh $120 \mathrm{~g}$ at commercial harvest. However, the bulk of the fruit for commercial harvest has ranged from 5.7 to $6.4 \mathrm{~cm}$ in diameter.

Fruit has yellow, fine-textured and, in our judgment, good-flavored flesh, is slightly red next to the pit, and has little to no protrusion at the apex. We rate the flesh moderately firm and resistant to browning on cut sur- faces. The pit is free from the flesh when fruit is soft ripe and is classified as semifree. Fruit surface varies in red blush from $60 \%$ to $75 \%$ of the area and has medium pubescence. The suture is smooth. Fruit ripens $\approx 80$ days from bloom in the Lower Rio Grande Valley.

The trees me vigorous and spreading, and respond readily to pruning to the vase system with open centers. Trees set a moderate number of flower buds and require extensive fruit thinning in the absence of spring frost. When properly managed, trees produce heavy crops of large-sized fruit for maturity early in the season. Leaf glands are globose. The trees are susceptible to rust [Tranzschelia discolor (F. Chl.) Tranz and Litn.] and have not been evaluated for resistance to bacterial spot [Xanthomonas campestris pv. pruni (Smith) Dye] but we assume it to be moderately tolerant, as is 'EarliGrande'.

'ValleGrande' trees require about 200 chilling units. A chilling unit is the maximum amount of chilling that can be satisfied in 1 hour at an optimum temperature. The optimum temperature for chilling in low-chill peach cultivars may be as high as $13 \mathrm{C}$ (Gurdian and Biggs, 1964). Trees will set and mature a full crop with slightly fewer than the required chilling units, but flowering and foliation may be delayed from 5 to 10 days.

Tree vigor, fruit production, and fruit
Table 1. Performance of 'ValleGrande' and comparable peach cultivars fruited at Weslaco, Texas (1983-88).

\begin{tabular}{lcclccc}
\hline \hline Cultivar & $\begin{array}{c}\text { Chilling } \\
\text { units }^{2}\end{array}$ & $\begin{array}{c}\text { Days from full } \\
\text { bloom to ripe }\end{array}$ & $\begin{array}{c}\text { Flower } \\
\text { type }\end{array}$ & $\begin{array}{c}\text { Flower } \\
\text { bud set }^{y}\end{array}$ & $\begin{array}{c}\text { Leaf } \\
\text { glands }\end{array}$ & $\begin{array}{c}\text { Bacterial } \\
\text { spot } \\
\text { resistance }\end{array}$ \\
\hline EarliGrande & 200 & $73-77$ & Nonshowy & 6 & Globose & 10 \\
Flordaprince & 150 & $78-83$ & Showy & 7 & Reniform & 4 \\
ValleGrande & 200 & $80-85$ & Nonshowy & 6 & Globose & 10 \\
TropicBeauty & 150 & $85-94$ & Showy & 10 & Reniform & 6 \\
TropicSweet & 175 & $90-100$ & Showy & 10 & Reniform & 6 \\
FlordaGrande & 100 & $100-105$ & Showy & 9 & Reniform & 9 \\
\hline
\end{tabular}

${ }^{2}$ According to relative order and time of bloom.

'Rated on a scale of 1 to 10 , where 10 is most desirable.

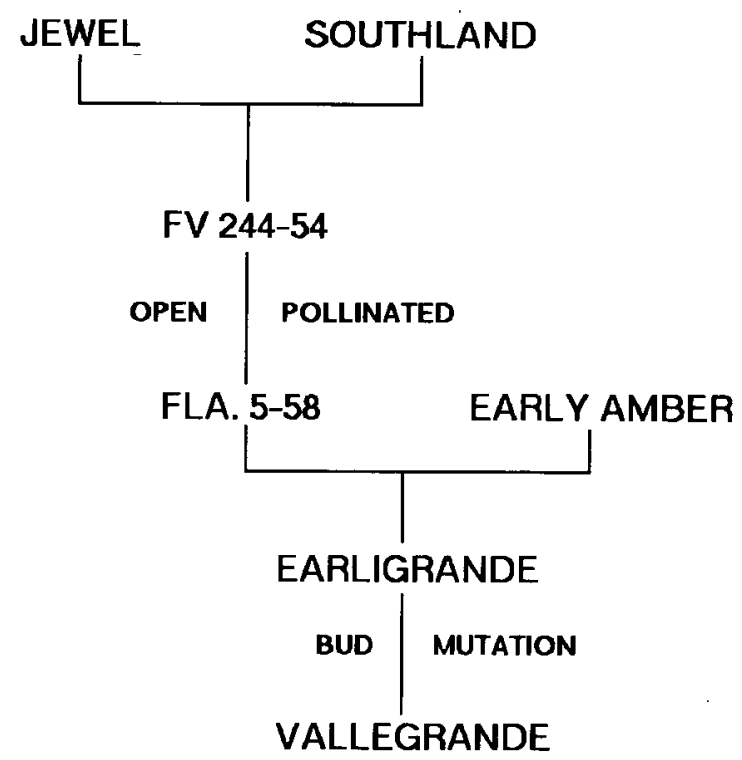

Fig. 1. Pedigree of 'ValleGrande' peach. 


\begin{tabular}{|c|c|c|c|c|c|c|c|c|}
\hline \multirow[b]{3}{*}{ Cultivar } & \multicolumn{5}{|c|}{ Fruit $^{2}$} & \multirow{2}{*}{\multicolumn{3}{|c|}{ Flesh $^{2, y}$}} \\
\hline & \multirow{2}{*}{$\begin{array}{c}\text { Blush } \\
(\%) \\
\end{array}$} & \multirow[b]{2}{*}{ Shape $^{y}$} & \multirow[b]{2}{*}{ Firm $^{y}$} & \multirow{2}{*}{$\begin{array}{c}\text { Weight } \\
(\mathrm{g})\end{array}$} & \multirow{2}{*}{$\begin{array}{c}\text { Stone } \\
\text { freeness }\end{array}$} & & & \\
\hline & & & & & & Taste & Texture & Browning \\
\hline EarliGrande & 40 & 7 & 6 & 90 & Semifree & 7 & 7 & 8 \\
\hline Flordaprince & 80 & 9 & 8 & 80 & Semifree & 8 & 7 & 7 \\
\hline ValleGrande & 65 & 8 & 8 & 120 & Semifree & 8 & 7 & 9 \\
\hline TropicBeauty & 80 & 10 & 10 & 100 & Semifree & 8 & 8 & 10 \\
\hline TropicSweet & 75 & 9 & 9 & 110 & Free & 9 & 9 & 9 \\
\hline FlordaGrande & 60 & 8 & 8 & 100 & Free & 8 & 8 & 8 \\
\hline
\end{tabular}

${ }^{2}$ All cultivars have yellow peel and flesh.

'Rated on a scale of 1 to 10 , where 10 is most desirable.

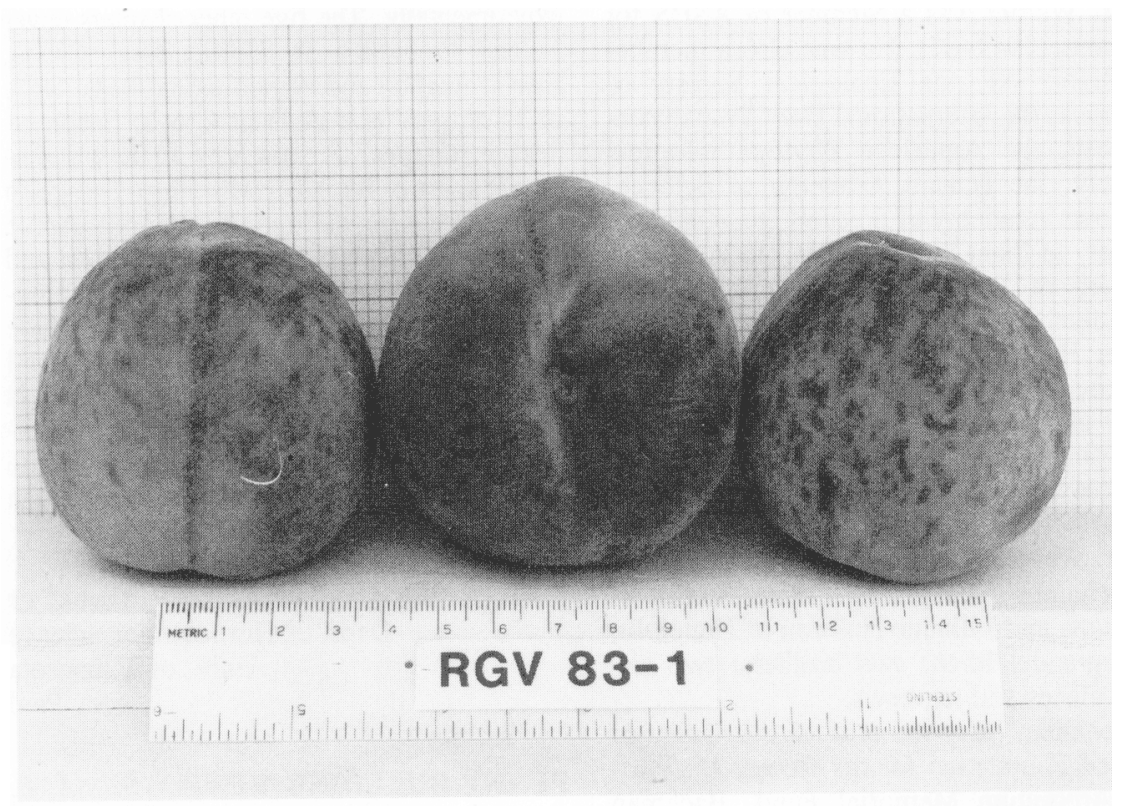

Fig. 2. Fruit of 'ValleGrande' peach.

quality of 'ValleGrande' have been high in the Lower Rio Grande Valley. Comparative performance and description of this cultivar and 'EarliGrande', 'Flordaprince', 'TropicBeauty', 'TropicSweet', and 'FlordaGrande' are given in Tables 1 and 2.

\section{Availability}

Limited quantities of budwood for 'ValleGrande' may be obtained from The Texas Agricultural Experiment Station, Weslaco, Texas 78596. Trees should be available from major fruit tree nurseries in the winter of 1990-1991.

\section{Literature Cited}

Bowen, H.H. 1980. 'EarliGrande' peach. HortScience 15:207.

Gurdian, R.J. and R.H. Biggs. 1964. Effect of low temperatures on terminating bud-dormancy of 'Okinawa', 'Flordawon', 'Flordahome', and 'Nernaguard' peaches. Proc. Fla. State Hort. Soc. 77:370-379.

Rouse, R.E. and W.B. Sherman. 1987. 'TropicSweet': A freestone peach for subtropical climates. HortScience 22: 169-170.

Rouse, R.E. and W.B. Sherman. 1989. 'TropicBeauty': A low-chilling peach for subtropical climates. HortScience 24:165-166.

Rouse, R. E., W.B. Sherman, and R.H. Sharpe. 1985. 'FlordaGrande': A peach for subtropical climates. HortScience 20:304-305.

Sherman, W. B., P.M. Lyrene, J.A. Mortensen, and R.H. Sharpe. 1982. 'Flordaprince' peach. HortScience 17:988. 